\title{
Transforming Growth Factor $\beta$ and Cyclosporin A Inhibit the Inducible Activity of the Interleukin-2 Gene in T Cells through a Noncanonical Octamer-Binding Site
}

\author{
THOMAS BRABLETZ, ${ }^{1}$ ISOLDE PFEUFFER, ${ }^{1}$ ELKE SCHORR, ${ }^{1}$ FRIEDERIKE SIEBELT, ${ }^{1}$ \\ THOMAS WIRTH, ${ }^{2}$ AND EDGAR SERFLING ${ }^{1 *}$ \\ Institute of Virology and Immunobiology, University of Würzburg, Versbacher Strasse 7, D-87 Würzburg, ${ }^{1}$ \\ and Center of Molecular Biology, Im Neuenheimer Feld, D-69 Heidelberg, ${ }^{2}$ Germany
}

Received 17 March 1992/Returned for modification 5 May 1992/Accepted 6 November 1992

\begin{abstract}
Transforming growth factor $\beta$ (TGF- $\beta$ ) has a growth-inhibitory effect on numerous different cell types of the immune system, including $T$ lymphocytes. We show in this study that the inhibitory action of TGF- $\beta$ on $T$ lymphocytes is accompanied by a block of interleukin 2 (IL-2) gene expression which is mediated, at least in part, by inhibition of IL-2 promoter/enhancer activity. The functional analysis of cis-regulatory (protoenhancer) elements of the IL-2 enhancer/promoter region showed that the most TGF- $\beta$-responsive element maps to its so-called upstream promoter site. The proto-enhancer activity of the upstream promoter site element is also inhibited by cyclosporin A. The upstream promoter site DNA harbors two noncanonical, closely linked binding sequences for octamer and AP-1-like factors. Both sites are involved in the establishment of IL-2 enhancer activity. Since the activity of genuine octamer sites but not that of AP-1-binding sites is also impaired by TGF- $\beta$ and cyclosporin A in El4 T lymphoma cells, we conclude that both immunosuppressives interfere with the activity but not the DNA binding of octamer factors in $T$ lymphocytes.
\end{abstract}

Transforming growth factor $\beta$ (TGF- $\beta$ ) belongs to a family of paracrine factors which are potent inhibitors of cellular proliferation (see reference 28 for a review). Numerous experimental studies have demonstrated that TGF- $\beta$ has a growth-inhibitory action on a variety of lymphoid cells, including $B$ and T lymphocytes $(12,19,20,43)$. TGF- $\beta$ is a very efficient inhibitor of pre-B-cell maturation, preventing expression of the immunoglobulin kappa light-chain locus $(26,29)$. Similarly, TGF- $\beta$ was found to interfere with the appearance of membrane immunoglobulin heavy-chain ( $\mathrm{IgH})$ molecules and the secretion of immunoglobulin proteins in $\mathrm{B}$ lymphocytes (19). Moreover, TGF- $\beta$ was found to suppress the generation of cytotoxic T cells (14), interleukin-2 (IL-2)dependent T-cell proliferation, and the upregulation of IL-2 and transferrin receptors (20).

A strong but quite different effect of TGF- $\beta$ on the synthesis and secretion of numerous cytokines has also been detected. In peripheral T lymphocytes, TGF- $\beta$ was able to suppress the synthesis of IL-2 and gamma interferon (12, $39)$, whereas in similar cell types, the synthesis of tumor necrosis factor $\alpha$ and $\beta$ appeared to be resistant to or even enhanced by the drug $(7,12)$. This quite selective effect of TGF- $\beta$ on a set of cytokines prompted us to compare the action of TGF- $\beta$ with that of the immunosuppressive agent cyclosporin A (CsA) at the molecular level. We and others have recently shown that CsA and its functional analog FK506 suppress early steps of T-cell activation through their interference with a few transcription factors that bind to the enhancer of the IL-2 gene $(4,10,35)$. In particular, CsA and FK506 inhibited the activity of NFAT-1, a lymphoid-specific factor binding to the two purine boxes of the IL-2 enhancer, and the activity of factors that bind to the enhancer's upstream promoter site (UPS). We will show here that the

* Corresponding author. latter site is specifically recognized by octamer and AP-1-like factors.

In nonlymphoid cell types, TGF- $\beta$ has been reported to exert its negative effect on numerous genes through a variety of binding motifs for transcription factors. In several rat cell lines, an inhibitory activity of TGF- $\beta$ on the transin/stromelysin promoter has been detected which appeared to be mediated through a noncanonical AP-1/Fos binding site (21). In other studies, an inhibitory effect of TGF- $\beta$ on the synthesis of jun mRNAs that results in suppression of AP-1-mediated gene activities has been reported $(16,22,25$, $27,46)$. In other reports, an effect of TGF- $\beta$ on expression of the c-myc gene which seems to be mediated through the protein product of the retinoblastoma $(\mathrm{Rb})$ gene has been reported $(28,30)$. A target site for the $\mathrm{Rb}$ protein within the fos promoter has been identified (36), and a similar site might exist within the c-myc promoter (30).

In this communication, we will show that in $\mathrm{T}$ lymphoma cells, TGF- $\beta$ inhibits the transcriptional induction of the IL-2 gene through closely linked noncanonical octamer and AP-1 binding motifs within the UPS of the IL-2 enhancer. TGF- $\beta$ impairs the activity of octamer factors in T and B lymphoma cells, whereas, in contrast to the situation in several other cell lines, the activity of AP-1-like factors remains unaffected by TGF- $\beta$ in T cells. Moreover, the activity of NF-kB-like factors was found to be slightly stimulated in T cells, and, contrary to the action of CsA, the activity of NFAT-1 was marginally inhibited. Since the activity of octamer factors was also found to be impaired by CsA in T but not in B lymphoma cells, TGF- $\beta$ and CsA differ in their inhibitory action on the IL-2 enhancer and octamer factors.

\section{MATERIALS AND METHODS}

Cell culture and transfection assays. Murine El4 T lymphoma cells and human Jurkat $T$ lymphoma cells were grown in RPMI medium supplemented with $5 \%$ fetal calf serum to 
a density of about $2 \times 10^{5}$ cells per ml. DNA $(20 \mu \mathrm{g})$ from the constructs described below (purified by two $\mathrm{CsCl}$ density gradient centrifugations) was transfected into about $5 \times 10^{7}$ El4 cells in a final volume of $3.6 \mathrm{ml}$ by the DEAE-dextran protocol as described earlier (42). One-fourth of the cells were pretreated for $15 \mathrm{~h}$ with TGF- $\beta(2.5 \mathrm{ng} / \mathrm{ml}$; from porcine platelets; H. Biermann GmbH, Bad Nauheim, Germany), and one-fourth were treated with CsA $(100 \mathrm{ng} / \mathrm{ml})$, and both treatments were followed by induction with $10 \mathrm{ng}$ of $12-\mathrm{O}$ tetradecanoyl-phorbol-13-acetate (TPA) per ml-2.5 $\mu \mathrm{g}$ of concanavalin A (ConA) per ml (TPA/ConA) in the presence of inhibitors. Another one-fourth was treated with TPA/ ConA alone, and the remaining one-fourth was used as the uninduced control. In cotransfection experiments (see Fig. 3B), $2.5 \mu \mathrm{g}$ of the $5 \times$ UPS chloramphenicol acetyltransferase (CAT) reporter construct was transfected into Jurkat cells along with $5 \mu \mathrm{g}$ of the Oct-2A expression vector pOEV1+ (31). After induction, the cells were incubated for $20 \mathrm{~h}$ in RPMI medium and sonicated, and their CAT values were measured after determination of the protein content as described before (42). The ratio of induction was calculated by dividing the percentage of chloramphenicol acetylation of induced cells (or of induced and TGF- $\beta$ - or CsA-treated cells) by the percentage of acetylation of uninduced cells. For the determination of luciferase activities (see Fig. 3C), cell extracts were prepared and assayed by the standard protocol (9). The expression levels were corrected for the protein concentration.

DNA cloning. All recombinant DNA work was done by standard procedures (38). The construction of the protoenhancer constructs $5 \times$ UPS, $5 \times$ TCEd, and $4 \times \mathrm{Pu}_{\mathrm{d}}$, containing multimers of the protein-binding sites of the IL-2 enhancer in front of the thymidine kinase $(t k)$ promoter of CAT vector pBLCAT2, has been described before $(4,5,35$, 42 ). Construct $5 \times$ UPS carries five copies of the UPS, spanning nucleotides from positions -64 to -94 of the IL-2 enhancer (4) (see Fig. 2B); $5 \times$ TCEd carries five copies of the $\kappa B$-like sequence from -191 to -215 (5); and $4 \times$ Pu- $_{\mathrm{d}}$ carries four copies of the distal purine box from -264 to -292 (35) (see Fig. 2A). Construct 5 $\times$ TREcoll contains five copies of the human collagenase promoter (2). Construct $4 \times$ Oct bears four copies of the 51-bp-long DdeI-HinfI fragment of the murine IgH enhancer (15) cloned in front of the $t k$ promoter in pBLCAT2. The luciferase reporter constructs $8 \times$ Oct-lucif and $8 \times$ Oct-M-lucif contain eight copies of either the octamer consensus sequence ATGCAAAT or the mutated sequence ATGAAAAT, respectively, in front of a truncated $t k$ promoter (spanning the promoter sequences up to position -38) and the luciferase gene (9). The IgH-E-CAT plasmid (a kind gift of I. Berberich), containing the intronic enhancer of the murine IgH gene, was constructed by inserting the $X b a I-E$ fragment from intron 2 of the IgH gene (3) in front of the tk promoter in pBLCAT2. The point mutation 152C within the TREp and the UPS mutations

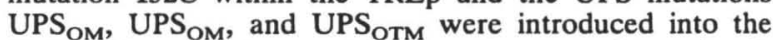
IL-2 wild-type enhancer by using the Amersham site-directed mutagenesis system followed by dideoxy sequencing, as recommended by the manufacturer. The following mutagenic primers were used:

$$
\begin{aligned}
& \text { 152C-TREp: (-142)5'-CTGATGACTGTCTGGAATTT-3'(-163) } \\
& \text { UPS }_{\text {TM: }} \text { : (-65)5'-CACGATGTTTTACATATTACACGTATTT-3' }(-92) \\
& \text { UPS }_{\text {OM }} \text { : }(-60) 5^{\prime} \text {-GOTGTCACGATGTTCCACATA-3' }(-80) \\
& \text { UPS }{ }_{\text {OTM }} \text { : } \quad(-69) 5^{\prime} \text {-ATGTTTTAQCGATTACACGTAT-3' }(-90)
\end{aligned}
$$

Isolation of nuclear proteins and EMSAs. Crude nuclear proteins of lymphoid cells were prepared by the procedure of

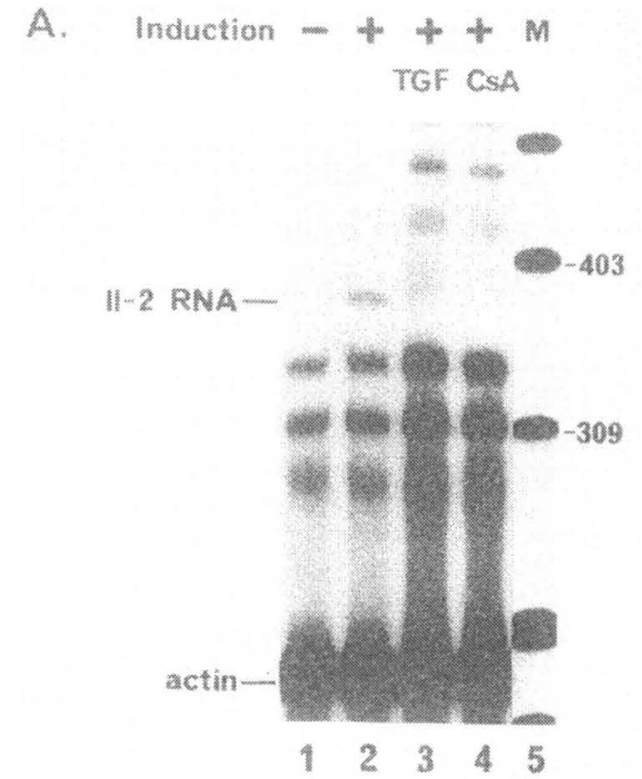

B.

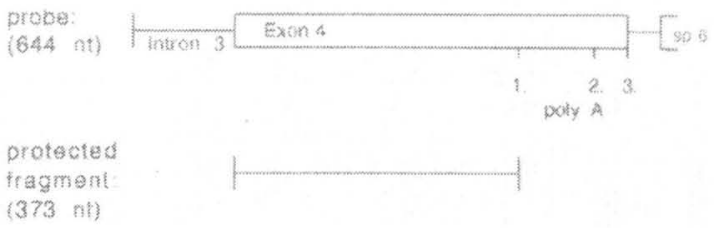

FIG. 1. TGF- $\beta$ and $\operatorname{Cs} A$ inhibit the appearance of authentic cytoplasmic IL-2 RNA upon induction of El4 T lymphoma cells. (A) Autoradiograph of an Sp6 RNA protection experiment. A 644nucleotide-long antisense Sp6 riboprobe of construct pGemII-E4R (44), shown in panel B, was hybridized to cytoplasmic RNA extracted from noninduced El4 cells (lane 1) or from El4 cells induced for $4 \mathrm{~h}$ with TPA/ConA (lane 2). Lanes 3 and 4, El4 cells treated for $12 \mathrm{~h}$ with $2.5 \mathrm{ng}$ of TGF- $\beta$ (lane 3 ) or $100 \mathrm{ng}$ of CsA (lane 4) before induction. After RNase treatment, the protected RNA probe was fractionated on a 5\% urea-polyacrylamide gel along with HpaII-digested pBR322 DNA as size markers (lane M). Note the appearance of a band of about 373 nucleotides, (nt), corresponding in size to correct IL-2 RNA transcripts (IL-2 RNA). The hybridization signal with an actin probe is also indicated.

Schreiber et al. (41). For the electrophoretic mobility shift assays (EMSAs), about $4 \mu \mathrm{g}$ of protein was incubated in a final volume of $15 \mu \mathrm{l}$ with 5,000 cpm (equivalent to about 0.2 $\mathrm{ng}$ ) for $20 \mathrm{~min}$ on ice along with $2 \mu \mathrm{g}$ of poly(dI $\cdot \mathrm{dC})$ by published procedures (40). After the incubation, the samples were fractionated in native $5 \%$ polyacrylamide gels at 200 $\mathrm{V} / 15 \mathrm{~cm}$ at room temperature. The gels were dried and exposed at $-70^{\circ} \mathrm{C}$. In the competition assays, a 25 - to 100 -fold excess (as specified in the figure legends) of unlabeled double-stranded oligonucleotide probes was added to the incubation mixture $5 \mathrm{~min}$ prior to the addition of the radioactively labeled probe.

RNA analysis. Whole RNA from El4 cells was extracted by the guanidinium thiocyanate procedure and centrifuged 


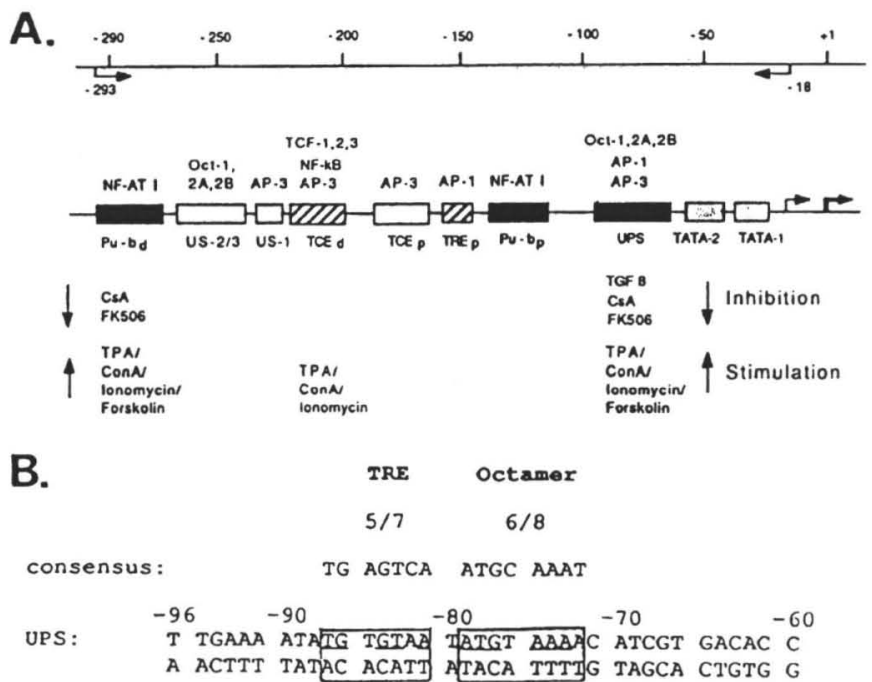

FIG. 2. Structure of the IL-2 enhancer and the sequence of its UPS. (A) IL-2 enhancer. The positions of protein-binding sites are indicated by boxes. The solid boxes indicate the CsA- and FK506-sensitive proto-enhancer elements, the two purine boxes $\left(\mathrm{Pu}-\mathrm{b}_{\mathrm{d}}\right.$ and $\mathrm{Pu}-\mathrm{b}_{\mathrm{p}}$ ), and the UPS (4). The hatched boxes indicate the CsA- and FK506-resistant (or distinctly less sensitive) proto-enhancer elements, namely the distal T-cell element TCEd (a kB-like binding site [5]) and the proximal TPA-responsive element TREp (a weak binding site of AP-1 [32]). The TCEp (which appeared to be inactive in proto-enhancer tests [4]) and the upstream sites US-1 and US-2/3 (the function of which is unknown) are indicated by open boxes; the two TATA boxes are indicated by stippled boxes. The binding of factors was determined in either DNase I footprint protection or EMSA experiments $(4,5,35,42)$ with purified factors (AP-1, AP-3, and NF-kB) or protein extracts from El4 T lymphoma cells. The vertical arrows below the enhancer show either the stimulation or inhibition of designated sequence elements by the indicated agents. (B) Sequence of UPS DNA. The binding sites of octamer and AP-1-like factors are boxed. The consensus sequences for the binding of octamer and AP-1 factors are written above the sequence, and the UPS nucleotides which match these sequences are underlined. The exact localization of factor-binding sites was determined in EMSA experiments with deletion and point mutations of UPS DNA (33).

through cesium chloride gradients as described before (38). For the Sp6 protection mapping of IL-2 RNA, an antisense Sp6 riboprobe of construct pGemII-E4R spanning exon 4 and part of exon 3 of the murine chromosomal IL-2 gene (44) was hybridized to whole RNA from El4 cells as described previously (42). After RNase treatment, the protected RNA probe was fractionated on a $5 \%$ polyacrylamide sequencing gel.

\section{RESULTS AND DISCUSSION}

In order to study the effect of TGF- $\beta$ on the inducible, T-lymphocyte-specific transcription of the IL-2 gene, we initially investigated the effect of TGF- $\beta$ on the accumulation of endogenous IL-2 RNA in El4 T lymphoma cells. El4 T cells synthesize and secrete large amounts of IL-2 after induction by the phorbol ester TPA or, to a greater extent, by TPA and a plant lectin, such as ConA. No IL-2 is synthesized in unstimulated El4 cells. This implies that important regulatory mechanisms controlling the correct transcription of the IL-2 gene are intact in these cells.

Sp6 RNase protection mapping of endogenous IL-2 RNA generated upon induction of El4 cells shows that the accumulation of mature cytoplasmic IL-2 RNA is efficiently blocked by low doses of TGF- $\beta(2.5 \mathrm{ng} / \mathrm{ml})$. The same effect was observed for CsA (Fig. 1). This suggests that TGF- $\beta$, like CsA (35), interferes with the transcriptional control of the murine IL-2 gene. In order to test this assumption, we studied the effect of TGF- $\beta$ on the activity of the IL-2 enhancer in transient-transfection assays. As expected, treatment of El4 cells with TGF- $\beta$ for $15 \mathrm{~h}$ led to a decrease in IL-2 enhancer-directed CAT activity to about one-third of the normal level (see Fig. 3A).

The murine IL-2 enhancer harbors numerous binding sites for protein factors and several proto-enhancer elements (Fig. $2 \mathrm{~A})$. The latter are binding sites for positive-acting transacting factors. When these sites are cloned in multiple copies in front of an indicator gene, they exhibit an inducible, T-cell-restricted activity like that of the entire IL-2 enhancer $(4,5,35,42)$. Previously, we and others showed that CsA and FK506 selectively inhibit the activity of purine boxes, the binding site of the lymphoid-specific factor NFAT-1, and of the UPS $(4,10,35)$ when they are added to the cells at the same time as (or after) the inducers. The activity of other sites, such as the $\kappa B$-like TCEd motif (5) or an AP-1 binding site, was not or only marginally affected by both drugs under the same conditions (4). The selective effect of CsA on the IL-2 enhancer sites (and factors) prompted us to investigate the effect of TGF- $\beta$ on these sites in transient-transfection experiments.

The results of these experiments, shown in Fig. 3A, indicate that in El4 T cells, TGF- $\beta$ quite selectively interferes with the inducible activity of the UPS motif. Similar to its inhibitory effect on the entire IL-2 enhancer, TGF- $\beta$ treatment of El4 cells resulted in a significant decrease in UPS-directed CAT activity, to about $20 \%$ of the normal level. TGF- $\beta$ did not exert any negative effect on the activity of ( $\mathrm{kB}$-like) factors binding to the TCEd motif, and in contrast to the result with CsA, the activity of Pu- $b_{d}$, a binding site of NFAT-1, was only weakly affected. Similarly, TGF- $\beta$ did not inhibit the activity of AP-1, since the inducible activity of a $5 \times$ TREcoll construct remained unaffected 


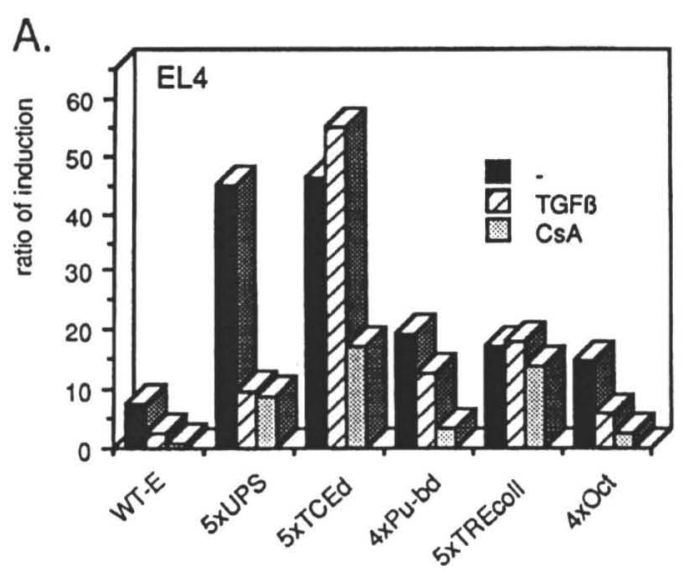

B.

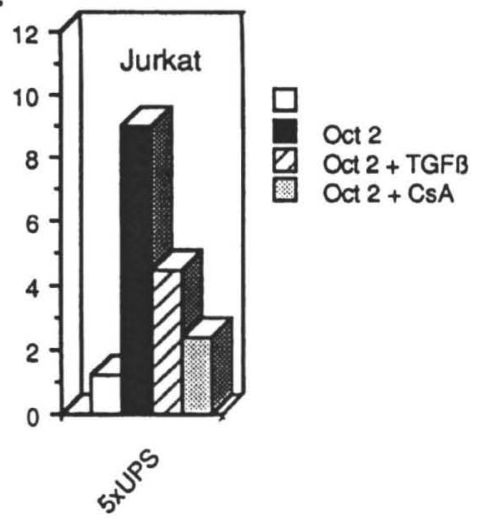

C.

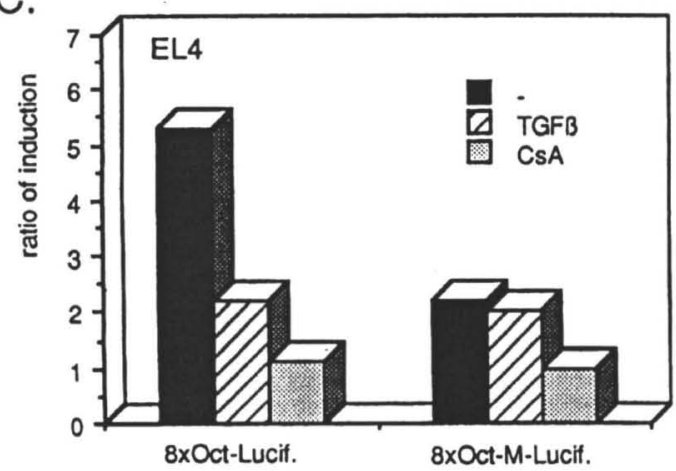

D.

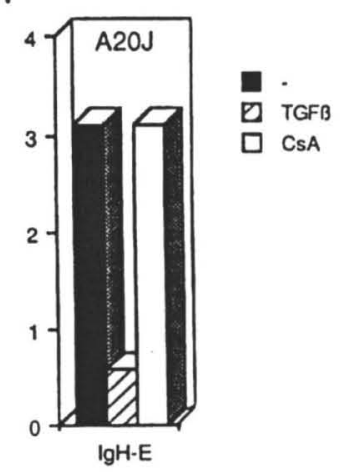

FIG. 3. TGF- $\beta$ and CsA suppress the inducible activity of the IL-2 enhancer and of octamer-binding sites in T lymphoma cells. (A) The effect of TGF- $\beta$ and CsA on the inducible activity of the IL-2 enhancer-CAT construct pILCAT2/1+ (WT-E), the IL-2 proto-enhancer-CAT plasmids $5 \times$ UPS, $5 \times$ TCEd, and $4 \times$ Pu- $b_{d}$, and the CAT constructs $5 \times$ TREcoll, carrying five copies of an AP- 1 consensus site $(2)$, and $4 \times 0 c t$, containing four copies of a 50-bp IgH enhancer fragment with its octamer consensus site (15). Plasmid DNAs (20 $\mu \mathrm{g}$ ) were transfected into about $5 \times 10^{7}$ El 4 cells by the DEAE-dextran method. After $20 \mathrm{~h}$, the cells were divided. One-fourth of the cells were incubated for $16 \mathrm{~h}$ with TGF- $\beta$ (2.5 ng/ml) (hatched columns), and one-fourth were incubated for $16 \mathrm{~h}$ with CsA $(100 \mu \mathrm{g} / \mathrm{ml}$ ) (stippled columns); both treatments were followed by induction with TPA/ConA for $20 \mathrm{~h}$ in the presence of inhibitors. Control cell cultures were either induced for $20 \mathrm{~h}$ with TPA/ConA (solid columns) or uninduced (not shown). Shown are the mean values for at least three (for $5 \times$ UPS, five) independent transfection experiments. (B) Transactivation of the $5 \times$ UPS construct by overexpressing Oct-2A in human Jurkat T lymphoma cells is impaired by TGF- $\beta$. DNA from $5 \times$ UPS $(2.5 \mu \mathrm{g})$ and $5 \mu \mathrm{g}$ of the Oct-2A expression vector pOEV1+ (31) were cotransfected into Jurkat cells by the DEAE-dextran method. One-fifth of the cells was used as an uninduced control, in which no Oct cDNA was cotransfected (not shown); the other aliquots were not cotransfected but were induced with TPA/ConA (open column) cotransfected and induced in the absence (solid column) or presence of Oct-2 plus TGF- $\beta$ (hatched column) or CsA (stippled column). The cells were treated and further processed as described for panel A. (C) TGF- $\beta$ and CsA impair the inducible activity of octamer factors in El 4 cells. Luciferase reporter constructs containing eight copies of either the octamer consensus sequence ATGCAAAT ( $8 \times$ Oct-lucif) or the mutated version ATGAAAAT ( $8 \times$ Oct-M-lucif) were transfected into El4 cells, which were treated as described for panel A. After incubation of the cells, extracts were prepared and analyzed for luciferase activity as described before (9). (D) The activity of the murine IgH enhancer is suppressed by TGF- $\beta$ but not by CsA in A20J B lymphoma cells. An IgH enhancer-CAT construct (containing the intronic XbaI-E fragment of the IgH gene [3]) was transfected into A20J cells. The cells were divided into four portions, and TGF- $\beta(2.5 \mathrm{ng} / \mathrm{ml})$ or CsA $(100 \mathrm{ng} / \mathrm{ml})$ was added to two portions. After $16 \mathrm{~h}$, lipopolysaccharide $(10 \mu \mathrm{g} / \mathrm{ml})$ and TPA $(50 \mathrm{ng} / \mathrm{ml}$ ) were added to the treated cells and to one portion of untreated cells (solid columns), while the remaining fourth was used as an uninduced control. After further incubation for $20 \mathrm{~h}$, the cells were harvested and the CAT activities were determined. In uninduced cells, the IgH enhancer construct showed a constitutive CAT activity of approximately $10 \%$. Shown are the mean values of three independent transfection experiments.

by TGF- $\beta$, while that of an IL-2 enhancer construct (designated $152 \mathrm{C}$-enhancer), containing a defect mutation within the TREp at its major binding site for genuine AP-1 (32), appeared to be inhibited, as the wild-type enhancer was (Fig. $3 \mathrm{~A}$ and 4$)$.

In DNase I footprint protection experiments with protein extracts from induced El4 cells or HeLa cells, about $30 \mathrm{bp}$ of UPS DNA was found to be protected against DNase I cleavage (42). When this sequence was used as a radioactive probe in EMSAs, three specific, prominent DNA-protein complexes were formed after incubation with crude nuclear extracts from induced and uninduced El4 lymphoma cells 


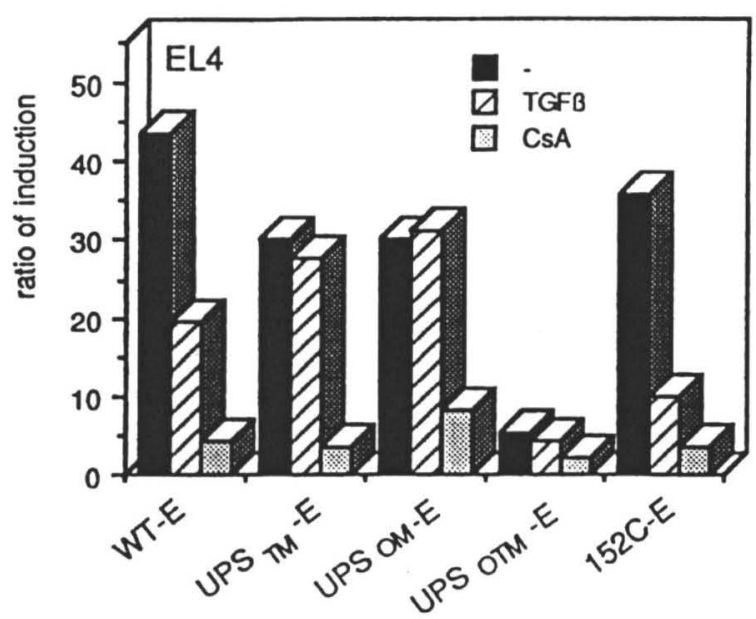

FIG. 4. Mutations within the UPS site which suppress factor binding render the inducible activity of the IL-2 enhancer resistant to TGF- $\beta$, while a defect mutation at the TREp site has no influence on the TGF- $\beta$ effect. IL-2-CAT constructs containing the IL-2 wild-type enhancer (WT-E), the UPS TM $_{\text {enhancer (UPS }}$ TM-E) containing a defective UPS AP-1 site, the UPS ${ }_{\mathrm{OM}}$ enhancer (UPS ${ }_{\mathrm{OM}}-\mathrm{E}$ ) containing a defective UPS Oct site, the UPS (UPS OTM $^{-E}$ ) containing both mutations in the UPS DNA, and the 152C-enhancer (152C-E) containing a defect mutation within the TREp were transfected into El4 cells as described in the legend to Fig. 3 and Materials and Methods. The cells were divided into fou portions; one-fourth were incubated for $16 \mathrm{~h}$ with TGF- $\beta(2.5 \mathrm{ng} / \mathrm{ml})$, and one-fourth were incubated for $16 \mathrm{~h}$ with CsA $(100 \mathrm{ng} / \mathrm{ml})$; both treatments were followed by induction with TPA/ConA for $20 \mathrm{~h}$ in the presence of inhibitors. The other two portions were either induced for $20 \mathrm{~h}$ with TPA/ConA (solid columns) or used as an uninduced control (not shown). The CAT activities were determined as described in the text. Shown are the mean values of three independent transfection experiments.

(Fig. 5A, lanes 1 to 5). Since identical complexes were also generated when a radioactive probe of the IgH enhancer carrying an octamer consensus sequence was used (Fig. 5A, lanes 6 to 8 ) and the formation of all three complexes could be inhibited by an excess of authentic octamer DNA (Fig. $5 \mathrm{~A}$, lane 4) but not by the same excess of an unrelated oligonucleotide (not shown), the formation of the three complexes must be due to the binding of octamer factors, probably the ubiquitous factor Oct-1 and the lymphoidspecific factors Oct-2A and Oct-2B (40). This conclusion is in line with published data on the binding of octamer factors to the same site of the human IL-2 enhancer (18) and is supported by our observation that the generation of Oct-1 and Oct- 2 complexes can be suppressed by preincubation of nuclear extracts with antibodies directed against the octamer proteins Oct-1 and Oct-2 (33).

However, octamer factors are not the only DNA-binding proteins which interact with the UPS DNA. In a previous publication, we have described the binding of purified AP-1 (and AP-3) to UPS DNA in DNase I footprint protection experiments (42), and Ullman et al. have reported the binding of a so-called octamer-associated protein, $O A P^{40}$, to the same site of the human IL-2 enhancer (45). In EMSA experiments with UPS DNA as the probe and a 100 -fold molar excess of authentic octamer DNA as the competitor, we observed one specific factor complex, the formation of which was not inhibited in the presence of the octamer DNA
(Fig. 5B, lane 2). The generation of this complex can be inhibited by a 100 -fold molar excess of TREcoll DNA (or another canonical AP-1 binding site) but not by the same excess of TCEd or Pu-b DNA (Fig. 5B, lanes 4 to 6). Moreover, incubation of UPS or TREcoll probes with bacterially expressed $v$-Jun resulted in the generation of identical factor complexes (Fig. 5B, lanes 7 to 10). This shows that AP-1-like factors are able to interact with UPS DNA sequences. According to all experimental data, they correspond to the OAP ${ }^{40}$ factor described recently (45). We will describe elsewhere our finding that AP-1-like factors interact with the sequence TGTGTAA, which is closely linked to the octamer-like binding sequence ATGTAAAA and shares five out of seven nucleotides with a canonical AP-1 binding sequence (Fig. 2B) (33). This site was described as the binding site of $\mathrm{OAP}^{40}$ in the human IL-2 enhancer (45).

The close linkage of binding sites for octamer and AP-1like factors within the UPS DNA and the resistance to TGF- $\beta$ of $5 \times$ TREcoll plasmids containing five AP- 1 binding sites (Fig. 3A) prompted us to investigate whether the activity of an authentic octamer site is also affected by TGF- $\beta$ and CsA. As the test plasmid, we initially used a tetrameric octamer-CAT plasmid bearing four copies of a 50 -bp-long DdeI-HinfI fragment from the murine IgH enhancer. This fragment has frequently been used for studying the binding and activity of octamer factors because its most prominent factor-binding site corresponds to a canonical octamer sequence (15). Like the activity of the $5 \times$ UPS-CAT construct, the activity of the $4 \times$ Oct-CAT plasmid was impaired by TGF- $\beta$ after transfection into El4 cells (Fig. 3A). However, in addition to the octamer motif, the DdeI-Hinfl fragment harbors further potential transcriptional factorbinding sites, like the $\mu \mathrm{E} 4$ motif (11) and the TRE half-site TGAC.

To show directly that the octamer motif is a target of TGF- $\beta$ repression and to rule out any contribution of these additional sites, we next tested reporter constructs that carried eight copies of either a synthetic wild-type or mutant octamer oligonucleotide upstream of a TATA box. The results of these transfection experiments are shown in Fig. $3 \mathrm{C}$ and indicate that the activity of canonical octamer sites is also impaired by TGF- $\beta$, although not as efficient as that of UPS DNA (about 40 versus $20 \%$ inhibition: compare Fig. 3C and 3A). Moreover, TGF- $\beta$ is also able to impair the activity of the IgH enhancer in B lymphoma cells (Fig. 3D). Since this has also been detected for the $4 \times$ Oct construct containing the IgH enhancer's octamer site (unpublished result), the TGF- $\beta$ effect in B cells might also be mediated through octamer factors. In contrast, CsA has no inhibitory effect on the IgH enhancer (Fig. 3D) and octamer factors in B cells (not shown).

In order to test whether the UPS site is the only target for TGF- $\beta$ within the IL-2 enhancer, we introduced into the enhancer three UPS mutations which suppressed the binding of either octamer factors (UPS OM $_{\text {) }}$, AP-1 (UPS TM $_{\text {) }}$, or both factors (UPS ${ }_{\text {OTM }}$ ) (33). When these IL-2-CAT constructs were transfected into El4 cells and tested in the presence of TGF- $\beta$ (or CsA), their reduced inducible activity appeared to be completely resistant to TGF- $\beta$ but not to CsA (Fig. 4). In contrast, a defect mutation of the TREp site at the enhancer's major site for the binding of genuine AP-1 did not lead to a loss of the TGF- $\beta$ effect (Fig. 4). This indicates that the UPS element is the most important site for mediating the TGF- $\beta$ effect, whereas CsA acts through the two NFAT-1 binding sites as well.

In cotransfection studies with the $5 \times$ UPS-CAT reporter 
A.

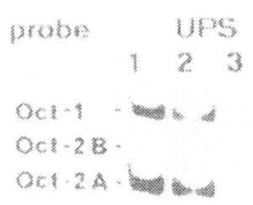

B.

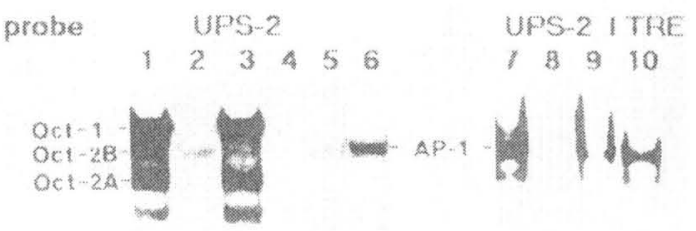

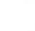

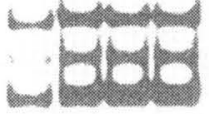

$\operatorname{comp}$ upi une

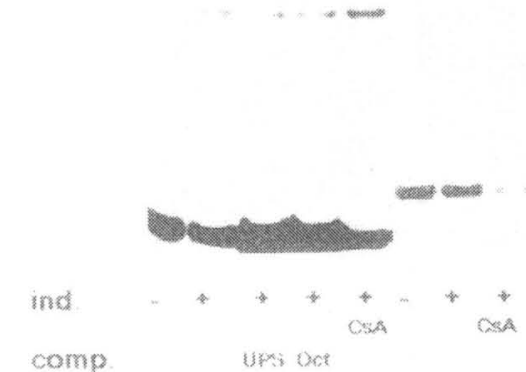

C. ups I Oct

12345678

Ocl -1

Oct -28

act-2 2

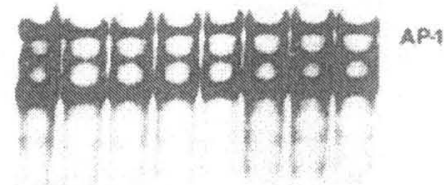

The

$\operatorname{Pun}_{d}$

9101112

13141516

$171819 \quad 20$

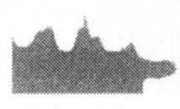

bact. vijun

are oe

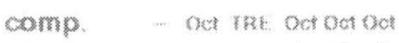

1द्: rot ne

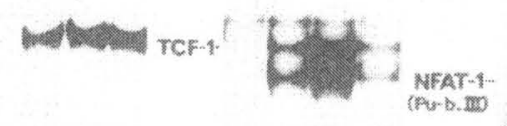

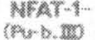

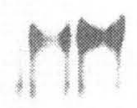

(4) 6
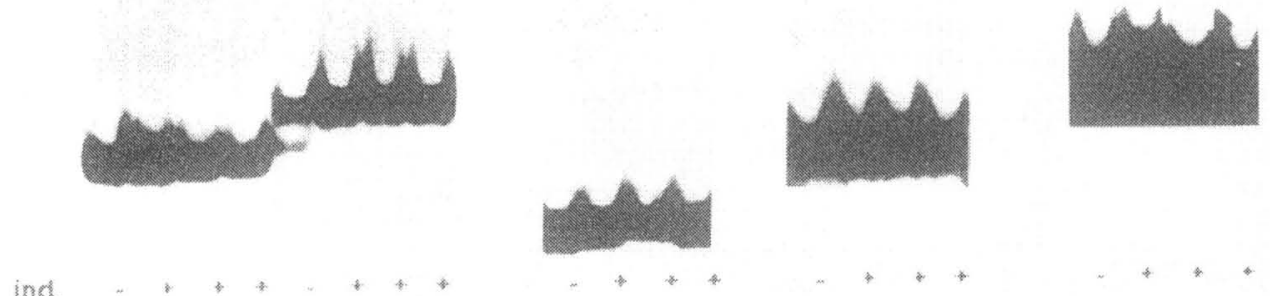

EQP Cra

(a) $\sin$

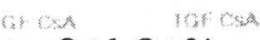

FIG. 5. Binding of octamer factors Oct-1, Oct-2A, and Oct-2B to UPS DNA is not impaired by TGF- $\beta$ or CsA. (A) UPS DNA represents a binding site for octamer factors Oct-1, Oct-2A, and Oct-2B. In EMSA experiments, a ${ }^{32}$ P-labeled UPS probe spanning the IL-2 enhancer DNA from positions -64 to -94 (lanes 1 to 5 ) or a probe consisting of the 51-bp-long DdeI-Hinfl fragment from the IgH enhancer containing a perfect octamer consensus sequence (15) (lanes 6 to 8 ) was incubated with $5 \mu \mathrm{g}$ of protein from crude nuclear extracts (41) of uninduced El4 cells (lanes 1 and 6) or cells treated with TPA/ConA for $4 \mathrm{~h}$ in the absence (lanes 2 and 7 ) or presence (lanes 5 and 8 ) of CsA (100 ng/ml). In lanes 3 and 4 , complex formation was inhibited by the addition of 50 ng of UPS or octamer DNA (the latter corresponds to a 15-bp oligonucleotide bearing an octamer consensus motif). (B) Detection of AP-1 factor binding to the UPS DNA. In lanes 1 to 6 , a ${ }^{32}$ P-labeled UPS- 2 probe (spanning nucleotides -68 to -90 of UPS DNA) was incubated with $5 \mu \mathrm{g}$ of protein from crude nuclear extracts of El4 cells induced with TPA/ConA for $4 \mathrm{~h}$. In the competition assays, $50 \mathrm{ng}$ of octamer DNA containing a perfect octamer site (lane 2), $50 \mathrm{ng}$ of TREcoll DNA (2) (lane 3), $50 \mathrm{ng}$ each of octamer and TREcoll DNAs (lane 4), $50 \mathrm{ng}$ each of octamer and TCEd DNA (spanning the IL-2 enhancer DNA from -191 to -215) (lane 5), or $50 \mathrm{ng}$ each of octamer and Pu-b, DNA (spanning the IL-2 enhancer DNA from -264 to -292) were used. The positions of octamer and AP-1 complexes are indicated. In lanes 7 to $10,4 \mu l$ of a bacterial lysate containing v-Jun 
construct and cDNA vectors that overexpress octamer and Jun/Fos proteins, we have observed a distinct functional synergism of these factors in their action through the UPS (33). This has also been detected for the inhibitory effect of CsA on UPS activity (33) and might explain why the activity of the UPS TM $_{\text {TM }}$ encer containing a defective UPS AP-1 site but intact UPS octamer site remained unaffected by TGF- $\beta$ (Fig. 4). Experiments are in progress to elucidate how this synergism ("cross-talk") between octamer and AP-1-like factors might occur at the molecular level.

Although TGF- $\beta$ inhibits the proto-enhancer activity of the UPS motif, it does not interfere with the factors binding to the UPS probe (Fig. 5C). In this respect, TGF- $\beta$ acts like CsA, which also interferes with the activity but not with the binding of factors to UPS DNA $(4,10)$. However, in striking contrast to CsA, TGF- $\beta$ does not have any negative influence on the binding of NFAT-1 to the purine box (Fig. 5C, lanes 17 to 20), nor did we detect any inhibitory effect of TGF- $\beta$ on the binding of AP-1 to the TREp (unpublished results) or, as shown in Fig. 5C (lanes 9 to 12), to the TREcoll. Frequently, we observed a distinct stimulation of binding of factors to the $\mathrm{kB}$-like TCEd element (Fig. 5C, lanes 13 to 16 ) or to authentic NF-kB binding sites (not shown). Taken together with the divergent effects of TGF- $\beta$ and CsA on the IgH enhancer in B cells (Fig. 3D), these data show that these drugs differ in their action on cellular signal transduction pathways.

How does TGF- $\beta$ interfere with the activity (but not with the DNA binding) of octamer factors? It is now widely accepted that the suppression of c-myc gene expression is one of the key events in the growth-inhibitory response to TGF- $\beta(28,30)$. The suppression of $c-m y c$ gene expression occurs at the transcriptional level (34). One likely candidate for mediating the inhibitory effect of TGF- $\beta$ on the $c-m y c$ promoter is $\mathrm{pRB}$, the protein product of the growth-suppressive retinoblastoma gene. The activity of $\mathrm{pRB}$ during the cel cycle is strictly regulated at the level of protein phosphorylation: $p R B$ was found to be underphosphorylated in the $G_{1}$ phase and hyperphosphorylated in the $S$ and $G_{2}$ phases $(6$, 8 ). The phosphorylation of $p R B$ in the late $G_{1}$ phase was found to be sensitive to TGF- $\beta$ (24). Several studies showed that the activity of octamer factor Oct-1 is also modulated in a cell cycle-dependent manner $(13,23)$, and, like pRB, Oct-1 seems to represent a general target for the activity of cel cycle-dependent protein kinases. In a recent study on the phosphorylation of Oct-1 in HeLa cells, Roberts et al. (37) detected distinct differences in the phosphorylation pattern of Oct-1 during different phases of the cell cycle. One of the protein kinases involved in Oct-1 phosphorylation is a p34 $4^{c d c 2}$-like kinase (37) which, in another system, was found to be inhibited by TGF- $\beta$ (17). Thus, it is tempting to speculate that in T lymphocytes, TGF- $\beta$ impairs the transcription of the IL-2 gene by affecting the phosphorylation of octamer factors that bind to the UPS motif of the IL-2 promoter through a block of $c d c 2$-mediated phosphorylation.

\section{ACKNOWLEDGMENTS}

We are indebted to Catherine Phillips for critical reading of the manuscript. For many helpful discussions, critical reading of the manuscript, and gifts of reagents, we thank P. Matthias (Basel). We are indebted to P. Angel (Karlsruhe), I. Berberich (Würzburg), B. Maurer (Würzburg), and H. J. Schluesener (Würzburg) for gifts of DNA constructs and reagents.

This work was supported by grants from the Deutsche Forschungsgemeinschaft, SFB 165 (Würzburg), and the Bundesgesundheitsamt, research program AIDS, grant no. II-087-89 (E. Serfling).

\section{REFERENCES}

1. Angel, P., E. A. Allegretto, S. T. Okino, K. Hattori, W. J. Boyle, T. Hunter, and M. Karin. 1988. Oncogene jun encodes a sequence-specific trans-activator similar to AP-1. Nature (London) 332:166-171.

2. Angel, P., M. Imagawa, R. Chiu, P. Stein, R. J. Imbra, H. J. Rahmsdorf, C. Jonat, P. Herrlich, and M. Karin. 1987. Phorbol ester-inducible genes contain a common cis element recognized by a TPA-modulated trans-acting factor. Cell 49:729-739.

3. Banerji, J., L. Olson, and W. Schaffner. 1983. A lymphocytespecific cellular enhancer is located downstream of the joining region in immunoglobulin heavy chain genes. Cell 33:729-740.

4. Brabletz, T., I. Pietrowski, and E. Serfling. 1991. The immunosuppressives FK 506 and cyclosporin A inhibit the generation of protein factors binding to the two purine boxes of the interleukin 2 enhancer. Nucleic Acids Res. 19:61-67.

5. Briegel, K., B. Hentsch, I. Pfeufer, and E. Serfling. 1991. One base pair change abolishes the $\mathrm{T}$ cell-restricted activity of a kB-like proto-enhancer element from the interleukin 2 promoter. Nucleic Acids Res. 19:5929-5936.

6. Buchkovich, K., L. A. Duffy, and E. Harlow. 1989. The retinoblastoma protein is phosphorylated during specific phases of the cell cycle. Cell 58:1097-1105.

7. Chantry, D., M. Turner, E. Abney, and M. Feldmann. 1989. Modulation of cytokine production by transforming growth factor- $\beta$. J. Immunol. 142:4295-4300.

8. DeCaprio, J. A., J. W. Ludlow, D. Lynch, Y. Furukawa, J. Grifin, H. Piwnica-Worms, C.-M. Huang, and D. M. Livingston. 1989. The product of the retinoblastoma susceptibility gene has properties of a cell cycle regulatory element. Cell 58:1085-1095.

9. de Wet, J. R., K. V. Wood, M. de Luca, D. R. Helinski, and S. Subramani. 1987. Firefly luciferase gene: structure and expression in mammalian cells. Mol. Cell. Biol. 7:725-737.

10. Emmel, E. A., C. L. Verweij, D. B. Durand, K. M. Higgins, E. Lacy, and G. Crabtree. 1989. Cyclosporin A specifically inhibits function of nuclear proteins involved in $\mathrm{T}$ cell activation. Science 246:1617-1620.

11. Ephrussi, A., G. M. Church, S. Tonegawa, and W. Gilbert. 1985. B lineage-specific interactions of an immunoglobulin enhancer with cellular factors in vivo. Science 227:134-140.

12. Espevik, T., I. S. Figari, M. R. Shalaby, G. A. Lackides, G. D. Lewis, H. M. Shepard, and M. A. Palladino. 1987. Inhibition of cytokine production by cyclosporin $\mathrm{A}$ and transforming growth factor $\beta$. J. Exp. Med. 166:571-576.

13. Fletcher, C., N. Heintz, and R. G. Roeder. 1987. Purification and characterization of OTF-1, a transcription factor regulating cell cycle expression of a human histone $\mathrm{H} 2 \mathrm{~b}$ gene. Cell 51:773-781.

14. Fontana, A., K. Frei, S. Bodmer, E. Hoefer, M. H. Schreier, M. A. Palladino, and R. M. Zinkernagel. 1989. Transforming growth factor- $\beta$ inhibits the generation of cytotoxic $T$ cells in virus-infected mice. J. Immunol. 143:3230-3234.

(1) was incubated with a UPS-2 DNA or TREcoll DNA probe under EMSA conditions (40). In lanes 8 and 9, 50 ng of TREcoll or octamer oligonucleotides were added for competition. (C) TGF- $\beta$ does not interfere with the DNA binding of octamer factors to UPS DNA. The indicated DNA probes were incubated with $4 \mu \mathrm{g}$ of protein from crude nuclear extracts of uninduced El 4 cells (lanes -) or El4 cells treated with TPA/ConA for $4 \mathrm{~h}$ in the absence (lanes +) or presence of TGF- $\beta$ ( $2.5 \mathrm{ng} / \mathrm{ml}$, lanes +TGF) or CsA (100 ng/ml, lanes +CsA). In the case of TGF- $\beta$ and CsA treatment, the cells were incubated with the drugs for $16 \mathrm{~h}$. Note the suppression of generation of the NFAT factor complex with the Pu-b probe by CsA but not by TGF- $\beta$ (lanes 19 and 20 ) and the CsA-induced inhibition but TGF- $\beta$-induced enhancement of binding of $\mathrm{\kappa B}$-like factors, including TCF-1 (5), to the $\mathrm{kB}$-like TCEd motif (lanes 14 to 16 ). 
15. Gerster, T., P. Matthias, M. Thali, J. Jiricny, and W. Schaffner. 1987. Cell-type specificity elements of the immunoglobulin heavy chain gene enhancer. EMBO J. 6:1323-1330.

16. Heino, J., and J. Massague. 1990. Cell adhesion to collagen and decreased myogenic gene expression implicated in the control of myogenesis by transforming growth factor $\beta$. J. Biol. Chem. 265:10181-10184.

17. Howe, P. H., G. Draetta, and E. B. Leof. 1991. Transforming growth factor $\beta 1$ inhibition of $\mathrm{p} 34^{\text {cdc2 }}$ phosphorylation and histone $\mathrm{H} 1$ kinase activity is associated with $\mathrm{G}_{1} / \mathrm{S}$-phase growth arrest. Mol. Cell. Biol. 11:1185-1194.

18. Kamps, M. P., L. Corcoran, J. H. LeBowitz, and D. Baltimore. 1990. The promoter of the human interleukin-2 gene contains two octamer-binding sites and is partially activated by the expression of Oct-2. Mol. Cell. Biol. 10:5464-5472.

19. Kehrl, J. H., C. Thevenin, P. Rieckmann, and A. S. Fauci. 1991. Transforming growth factor $\beta$ suppresses human B lymphocyte Ig production by inhibiting synthesis and the switch from the membrane to the secreted form of Ig mRNA. J. Immunol. 146: $4016-4023$

20. Kehrl, J. H., L. M. Wakefield, A. B. Roberts, S. Jakowlew, M. Alvarez-Mon, R. Derynck, M. B. Sporn, and A. S. Fauci. 1986. Production of transforming growth factor $\beta$ by human $T$ lymphocytes and its potential role in the regulation of $T$ cell growth. J. Exp. Med. 163:1037-1050.

21. Kerr, L. D., D. B. Miller, and L. M. Matrisian. 1990. TGF-B1 inhibition of transin/stromelysin gene expression is mediated through a Fos binding sequence. Cell 61:267-278.

22. Kim, S. J., P. Angel, R. Lafyatis, K. Hattori, K. Y. Kim, M. B. Sporn, M. Karin, and A. B. Roberts. 1990. Autoinduction of transforming growth factor $\beta 1$ is mediated by the AP-1 complex. Mol. Cell. Biol. 10:1492-1497.

23. LaBella, F., H. L. Sive, R. G. Roeder, and N. Heintz. 1988. Cell-cycle regulation of a human histone $\mathrm{H} 2 \mathrm{~b}$ gene is mediated by the $\mathrm{H} 2 \mathrm{~b}$ subtype-specific consensus elements. Genes Dev. 2:32-39.

24. Laiho, M., J. A. DeCaprio, J. W. Ludlow, D. M. Livingston, and J. Massague. 1990. Growth inhibition by TGF- $\beta$ linked to suppression of retinoblastoma protein phosphorylation. Cell 62:175-185.

25. Laiho, M., L. Rönnstrand, J. Heino, J. A. DeCaprio, J. W. Ludlow, D. M. Livingston, and J. Massague. 1991. Control of JunB and extracellular matrix protein expression by transform. ing growth factor $\beta 1$ is independent of simian virus $40 \mathrm{~T}$ antigen-sensitive growth-inhibitory events. Mol. Cell. Biol. 11: 972-978.

26. Lee, G., L. R. Ellingsworth, S. Gillis, R. Wall, and P. W. Kinkade. 1987. $\beta$ transforming growth factors are potentia regulators of B lymphopoiesis. J. Exp. Med. 166:1290-1299.

27. Li, L., J.-S. Hu, and E. N. Olson. 1990. Different members of the jun proto-oncogene family exhibit distinct patterns of expression in response to type $\beta$ transforming growth factor. J. Biol. Chem. 265:1556-1562.

28. Massague, J. 1990. The transforming growth factor- $\beta$ family. Annu. Rev. Cell Biol. 6:597-641.

29. Miller, C. L., A. L. Feldhaus, J. W. Rooney, L. D. Rhodes, C. H. Sibley, and H. Singh. 1991. Regulation and a possible stagespecific function of Oct-2 during pre-B-cell differentiation. Mol. Cell. Biol. 11:4885-4894.

30. Moses, H. L., E. Y. Yang, and J. A. Pietenpol. 1990. TGF- $\beta$ stimulation and inhibition of cell proliferation: new mechanistic insights. Cell 63:245-247.

31. Müller, M. M. S. Ruppert. W. Schafiner, and P. Matthias. 1988. A cloned octamer transcription factor stimulates transcription from lymphoid-specific promoters in non-B cells. Nature (London) 336:544-551.

32. Müller-Deubert, S., E. Bohn, S. Chuvpilo, B. Hentsch, U. Korthäuer, I. Pfeuffer, C. Schomberg, R. Kroczek, A. Schimpl, and E. Serfling. Submitted for publication.

33. Pfeuffer, I., T. Brabletz, S. Klein-Heßling, B. Hentsch, P. Matthias, and E. Serfling. Unpublished data.

34. Pietenpol, J. A., J. T. Holt, R. W. Stein, and H. L. Moses. 1990 Transforming growth factor $\beta 1$ suppression of c-myc gene transcription: role in inhibition of keratinocyte proliferation. Proc. Natl. Acad. Sci. USA 87:3758-3762.

35. Randak, C., T. Brabletz, M. Hergenröther, I. Sobotta, and E. Serfling. 1990. Cyclosporin A suppresses the expression of the interleukin 2 gene by inhibiting the binding of lymphocytespecific factors to the IL-2 enhancer. EMBO J. 9:2529-2536.

36. Robbins, P. D., J. M. Horowitz, and R. C. Mulligan. 1990 Negative regulation of human c-fos expression by the retinoblastoma gene product. Nature (London) 346:668-671.

37. Roberts, S. B., N. Segil, and N. Heintz. 1991. Differential phosphorylation of the transcription factor Octl during the cell cycle. Science 253:1022-1026.

38. Sambrook, J., E. F. Fritsch, and T. Maniatis. 1989. Molecular cloning: a laboratory manual, 2nd ed. Cold Spring Harbor Laboratory, Cold Spring Harbor, N.Y.

39. Schluesener, H. J., and O. Lider. 1989. Transforming growth factors $\beta 1$ and $\beta 2$ : cytokines with identical immunosuppressive effects and a potential role in the regulation of autoimmune $T$ cell function. J. Neuroimmunol. 24:249-258.

40. Schreiber, E., P. Matthias, M. M. Müller, and W. Schaffner. 1988. Identification of a novel lymphoid specific octamer binding protein (OTF-2B) by proteolytic clipping bandshift assay (PCBA). EMBO J. 7:4221-4229.

41. Schreiber, E., P. Matthias, M. M. Müller, and W. Schamer. 1989. Rapid detection of octamer binding proteins with "miniextracts", prepared from a small number of cells. Nucleic Acids Res. 17:6419.

42. Serfling, E., B. Barthelmäs, I. Pfeuffer, B. Schenk, S. Zarius, R. Swoboda, F. Mercurio, and M. Karin. 1989. Ubiquitious and lymphocyte-specific factors are involved in the induction of the mouse interleukin 2 gene in T lymphocytes. EMBO J. 8:465473.

43. Siepl, C., S. Bodmer, K. Frei, H. R. MacDonald, R. DeMartin E. Hofer, and A. Fontana. 1988. The glioblastoma-derived T cell supressor factor/transforming growth-factor $\beta 2$ inhibits $T$ cell growth without affecting the interaction of interleukin 2 with its receptor. Eur. J. Immunol. 18:593-600.

44. Swoboda, R., E. Wecker, and A. Schimpl. 1987. Regulation of I12 expression in mitogen-activated murine T-lymphocytes. Immunobiology 174:300-312.

45. Uliman, K. S., W. M. Flanagan, C. A. Edwards, and G. R. Crabtree. 1991. Activation of early gene expression in T lymphocytes by Oct-1 and an inducible protein, OAP ${ }^{40}$. Science 254:558-562.

46. Zentella, A., F. M. B. Weis, D. A. Ralph, M. Laiho, and J. Massague. 1991. Early gene responses to transforming growth factor $\beta$ in cells lacking growth-suppressive RB function. Mol. Cell. Biol. 11:4952-4958. 